\title{
OCCUPATIONAL WELL-BEING GURU BERDASARKAN STATUS KEPEGAWAIAN
}

Faizah, Alif Bagaskara Ajeng Wilutama Jurusan Psikologi Universitas Brawijaya

faizah_hermawan@ub.ac.id, abagasakara99@gmail.com

\begin{abstract}
ABSTRAK. Penelitian ini bertujuan untuk mengetahui Occupational well-being berdasarkan status kepegawaian guru (guru tetap dan honorer). Penelitian ini menggunakan metode kuantitatif dengan teknik analisis Independent Sample T-Test untuk mengetahui occupational well-being antara guru tetap dengan guru honorer dengan sampel 80 guru tetap dan 80 guru honorer yang diambil menggunakan accidental sampling. Skala dan alat ukur yang digunakan adalah The Well-being At Your Work Index Questionnare milik Laine (2018). Dari hasil uji hipotesis didapatkan signifikansi sebesar $0.465(\alpha>0,05)$, yang berarti tidak terdapat perbedaan occupational well-being pada guru tetap dan guru honorer.
\end{abstract}

Kata Kunci : Occupational Well-being, Guru.

\begin{abstract}
This study aims to understanding Occupational well-being teachers based on employment status. The research is a quantitative method using the Independent Sample T-Test technique to determine the differences in occupational well-being based on employment status with a sample of 80 permanent teachers and 80 honorary teachers taken using accidental sampling. The scale and measuring instrument used is The Well-being At Your Work Index Questionnare owned by Laine (2018). From the results of the hypothesis test obtained significance of $0.465(\alpha>0.05)$, which means there is no differences occupational well-being teachers based on employment status.
\end{abstract}

Keywords: Occupational Well-being, Teacher.

\section{PENDAHULUAN}

Perkembangan peserta didik salah satunya didukung dengan kehadiran guru. Guru memiliki peran yang penting dalam pendidikan karena profesinya sebagai pengajar di sekolah ataupun di tempat lain. Menurut Meiza (2016), guru merupakan pendidik yang melakukan pendidikan di tempat tertentu, baik di lembaga formal ataupun non formal. Guru adalah sebutan jabatan, posisi, dan profesi, bagi seseorang yang mengabdikan dirinya dalam bidang pendidikan melalui interaksi edukatif secara terpola, formal, dan sistematis (Shabir, 2015).

Secara profesional guru memiliki tanggung jawab yang besar terhadap perkembangan moral dan pengetahuan peserta didik karena guru memiliki tugas untuk langsung mendampingi dan mengarahkan peserta didik. Menurut Ramadhan (2017), guru 
memiliki tugas mempersiapkan pola pemikiran manusia untuk masa depan.

Secara sistematis guru dibedakan menjadi beberapa pengelompokan diantaranya guru tetap dan guru honorer. Guru tetap merupakan guru yang memiliki kewenangan khusus di suatu sekolah yang sudah diakui oleh pemerintah Indonesia, sedangkan guru honorer adalah guru yang diangkat oleh pejabat yang berwenang untuk membantu tenaga pendidik di sekolah (Balkis dan Masykur, 2016).

Beberapa permasalahan guru yang muncul adalah tentang beban kerja yang tinggi, upah yang tidak merata, dan juga tidak adanya jenjang karir bagi guru. Menurut (Chatib, 2011) permasalahan guru saat ini belum mendapatkan perhatian sepenuhnya dari pemerintah terutama pada guru honorer. Nurwana (2013), menambahkan ada beberapa faktor yang dapat mempengaruhi permasalahan guru yaitu faktor intrinsic rewards dan extrinsic rewards. Faktor intrinsic rewards yang dimaksud adalah aspek - aspek yang meliputi partisipasi dalam pengambilan keputusan, pemberian kewenangan, komunikasi dengan atasan, signifikasi tugas pekerjaan, pemberian rasa adil yang merata, peningkatan karir, dan variasi tugas. Untuk faktor extrinsic rewards meliputi aspek imbalan berupa gaji, fasilitas tambahan, kesempatan menduduki jabatan tertentu, dan jaminan kerja dan juga imbalan dari interaksi sosial yang terjalin dari dukungan atasan, dukungan teman kerja serta kekompakan dengan kelompok kerja yang ada.
Permasalahan yang mencolok saat ini adalah beban kerja bagi guru yaitu 40 jam kerja dalam satu minggu. Artinya guru bekerja satu hari minimal 8 jam kerja baik dalam kondisi mengajar ataupun mempersiapkan keperluan belajar mengajar. Menurut Hamid Muhammad (dalam Kemendikbud, 2018), bahwa beban kerja guru tidak hanya untuk tatap muka tetapi semua komponen beban kerja mulai dari merencanakan pembelajaran, mempersiapkan pembelajaran, menilai hasil pembelajaran, membimbing dan melatih peserta didik, serta memberikan tugas tambahan sesuai dengan kegiatan pokok sehingga hal tersebut membuat beberapa guru harus mencari jam mengajar tambahan ke sekolah lain untuk dapat memenuhi beban kerjanya. Sebagai mana yang diungkapkan oleh Lufri (2013), bahwa permasalahan yang muncul terhadap beban kerja guru yaitu banyak guru tetap yang mencari jam mengajar tambahan ke sekolah lainnya agar mencukupi jam kerja yang telah ditentukan oleh pemerintah sehingga guru tidak punya tenaga untuk mempersiapkan pembelajaran yang baik. Sedangkan, untuk guru honorer mendapatkan jam mengajar yang sedikit karena banyaknya jam mengajar yang dibutuhkan oleh guru tetap.

Permasalahan beban kerja guru mempengaruhi banyak faktor. Salah satunya adalah keletihan saat proses pengajaran, seperti yang diungkapkan Saaranen (2007), tekanan pekerjaan, keletihan, kepuasan guru terhadap pekerjaan didasarkan beban kerja mental guru terhadap proses pengajaran. Tekanan pekerjaan 
dan keletihan guru tentu mepengaruhi aspek aspek occupational well-being.

Occupational well-being diartikan sebagai kesejahteraan kerja yang dipengaruhi oleh berbagai aspek yang mendukung kondisi kerja, sumber daya yang sesuai dengan beban kerja, komunitas kerja yang sesuai dengan fungsinya, dan kompetensi profesional pekerja (Saaranen, 2007). Juniper (dalam Saaranen, 2015), menambahkan kurangnya kesejahteraan kerja karena perhatian terhadap beban kerja dengan kemampuan kerja sangat minimal. Kesejahteraan kerja bisa didapat karena beban kerja, kemampuan sumber daya manusia dan fasilitas kerja yang seimbang dan ditunjang dengan manajemen organisasi kerja, model kepemimpinan, dukungan sosial, serta komunikasi kerja yang baik (Saaranen, 2015).

Dari berbagai aspek Occupational well-being memiliki banyak faktor yang mempengaruhi, contohnya adalah 1) Lingkungan kerja fisik yang diartikan sebagai fasilitas kerja yang mendukung posisi kerja, keselamatan kerja dari faktor biologis dan kimia. 2) Kesehatan kerja yang diartikan sebagai kebugaran fisik dan mental dalam bekerja. 3) Manajemen organisasi kerja yang baik. 4) Model kepemimpinan yang baik. 5) Dukungan sosial dan komunikasi yang baik dengan komunitas pekerja. 6) Pendidikan yang sesuai dengan pekerjaan dan jabatan yang dimiliki (Saaranen, 2007). Saaranen (2015), menambahkan aspek - aspek tersebut memiliki kesinambungan untuk mengembangkan kesejahteraan kerja
Hasil dari penelitian Saaranen (2007), komunitas pekerja dalam sekolah kurang mencapai suasana kerja yang baik dikarenakan infrastruktur yang kurang memadai. Laine (2018), menambahkan bahwa kesejahteraan kerja atau Occupational Well-being berdampak pada kesehatan dan kesejahteraan manusia yang dapat diukur dari aspek pekerja dan pekerjaan, komunitas kerja, hubungan pemimpin dengan bawahan yang baik dan juga kompetensi profesional yang seimbang. Penelitian yang dilakukan Zetriuslita \& Wahyuni (2013), menyebutkan bahwa guru kurang bisa mengembangkan komunikasi dengan rekan kerja ataupun lembaga lain sesuai dengan kapasitasnya. Dari hasil beberapa penelitian tersebut dapat diartikan kesejahteraan guru kurang mendapat perhatian, sehingga staf pada sekolah dianjurkan untuk memberi budaya komunikatif untuk menciptakan infrastruktur dan lingkungan yang memadai. (Saaranen, 2007), mengatakan sebaiknya antara staff, guru, ataupun karyawan lain membudayakan komunikasi yang baik untuk menciptakan lingkungan yang memadai untuk bekerja.

\section{METODE}

Penelitian ini menggunakan metode kuantitatif dengan desain korelasi untuk mengetahui adanya perbedaan occupational well-being antara guru tetap dengan guru honorer. Pada penelitian ini, peneliti menggunakan satu skala penelitian yaitu The Well-being at Your Work Index Questionnaire (Liane, 2018) dengan menggunakan dasar teori 
milik Saaranen (2006). Populasi pada penelitian adalah guru tetap dan guru hororer yang dilakukan secara accidental sampling. Skala mengenai occupational well-being terhadap empat aspek yaitu worker and work, working conditions, professional competence, dan working community. Skala The Well-being At Your Work Index Questionnare (Liane, 2018) memiliki nilai Cronbach's Alpha dengan rentang nilai $0.53-0.89$. Reliabilitas Cronbach's Alpha dengan program SPSS 17.0 for windows dengan nilai 0.867. Analisis data menggunakan metode independent sample $t$ test.

\section{HASIL}

Occupational Well-being yang mengacu pada skor mean $(\mu)$, dan standar deviasi $(\sigma)$, kategorisasi guru honorer memiliki nilai Occupational Well-being dengan mayoritas tinggi yaitu 55 guru honorer dengan presentasi $68.8 \%$. Sedangkan pada nilai kebutuhan yang sedang ada 21 guru dengan $26.3 \%$ dan juga kebutuhan yang rendah ada 4 guru honorer dengan presentase $5 \%$. kategorisasi guru tetap memiliki nilai Occupational Well-being mayoritas tinggi yaitu 58 guru tetap dengan $72.5 \%, 17$ guru tetap yang memiliki nilai sedang dengan presentasi $21.3 \%$, dan 5 guru tetap yang memiliki nilai rendah dengan presentasi 6.3\%. Occupational well-being pada guru honorer dan guru tetap menunjukan signifikansi sebesar $0.465(\alpha>0,05)$, yang berarti bahwa tidak terdapat perbedaan occupational well-being secara siginfikan pada guru tetap dan guru honorer.

\section{PEMBAHASAN}

Hasil perhitungan menurut kategorisasi menunjukan guru tetap dan guru honorer memiliki nilai mayoritas yang tinggi. Guru honorer memiliki nilai sebesar $68.8 \%$, sedangkan pada guru tetap menunjukan $72.5 \%$. Pada kategori sedang guru honorer memiliki nilai $26.3 \%$ sedangkan guru tetap memiliki nilai $21.3 \%$ dan pada kategori rendah guru hunorer memiliki nilai 5\%, sedangkan guru tetap memiliki nilai $6.3 \%$. Nilai kategorisasi yang mayoritas tinggi tersebut menunjukan bahwa subjek membutuhkan dimensi Occupational Well-being dalam bekerja. Hal tersebut dikuatkan oleh penelitian tentang kesejahteraan kerja anggota staf yang dilakukan oleh Saaranen (2015), yaitu occupational well-being menjadi kerangka penting untuk mengembangkan kesejahteraan staf kerja sekolah yang diteliti pada tahun 2002 dan 2004. Berdasarkan hasil penelitian tersebut beban kerja dan tekanan kerja terhadap guru mengakibatkan kesejahteraan umum yang rendah. Kesejahteraan yang rendah harus segera diberikan penangan melalui aspek komunitas kerja dengan penghargaan terhadap kinerja orang lain.

Laine (2018), menguatkan dengan melakukan pengembangan penelitian menggunakan teori Saaranen dan juga melihat perkembangan occupational well-being di sekolah yang menjadi sampel Saaranaen di 
tahun 2002, 2004, 2007, dan 2015. Laine (2018) menunjukan bahwa subjek yang dipilih di sekolah yang menjadi sampel memenuhi aspek occupational well-being untuk meningkatkan kesejahteraan kerja sehingga semakin tinggi respon bagi subjek terhadap occupational well-being menunjukan bahwa aspek - aspek tersebut dibutuhkan. Laine (2018), juga menyebutkan bahwa aspek seperti pekerja dan pekerjaan, kondisi kerja, kompetensi profesional, dan komunitas kerja saling terhubung untuk menjadikan kesejahteraan bagi guru dan staf sekolah.

Terlepas dari hasil kategorisasi, ditinjau dari hasil uji hipotesis independent sample t-test, hasil signifikansi yang didapat yaitu sebesar 0,465 yang dapat dikatakan bahwa tidak terdapat perbedaan antara occupational well-being pada guru honorer dan guru tetap. Hasil tersebut menguatkan teori Laine (2018), yang menunjukan bahwa semua guru membutuhkan kesejahteraan yang tinggi.

Penelitian tersebut dikuatkan oleh penelitian sebelumnya yang membahas tentang perbandingan tingkat kepuasan kerja antara guru tetap dan guru honorer pada unit pelaksana teknis dinas pendidikan Kecamatan Kasui Kabupaten Waykanan yang dilakukan oleh Nurwana (2013), penelitian yang dilakukan tersebut untuk mendapatkan informasi tentang perbandingan tingkat kepuasan kerja antara kelompok guru SD yang berstatus tetap atau PNS dengan kelompok guru yang berstatus honorer. Hasil penelitian tersebut menunjukan nilai guru honorer memiliki kecenderungan skor rata - rata di atas nilai tengah kepuasan kerja. Berbeda sedikit dengan guru tetap atau PNS yang memiliki kecenderungan skor cukup puas. Hasil tersebut ditinjau dari faktor intrinsic rewards dan extrinsic rewards. Faktor intrinsic rewards yang dimaksud adalah aspek - aspek yang meliputi partisipasi dalam pengambilan keputusan, pemberian kewenangan, komunikasi dengan atasan, signifikasi tugas pekerjaan, pemberian rasa adil yang merata, peningkatan karir, dan variasi tugas. Untuk faktor extrinsic rewards meliputi aspek imbalan berupa gaji, fasilitas tambahan, kesempatan menduduki jabatan tertentu, dan jaminan kerja dan juga imbalan dari interaksi sosial yang terjalin dari dukungan atasan, dukungan teman kerja serta kekompakan dengan kelompok kerja yang ada.

Nurwana (2013), menyebutkan kepuasan kerja paling ditentukan oleh besarnya pendapatan gaji. Namun, Nurwana (2013), juga menyebutkan bahwa dengan mengacu dari hasil penelitiannya ada faktor lain yang secara bersamaan ikut mempengaruhi tingkat kepuasan kerja yaitu unsur tingkat pendidikan dan unsur gaji total.

\section{KESIMPULAN}

Tidak terdapat perbedaan occupational well-being antara guru tetap dan guru

honorer. Sebaiknya penelitian selanjutnya melakukan konstruksi alat ukur occupational well-being dan memperhatikan latar belakang subjek penelitian. 


\section{DAFTAR PUSTAKA}

Aritonang, R. L. (2007). Riset Pemasaran: Teori dan Praktik (1 ed.). Bogor: Ghalia Indonesia.

Aritonang, R., \& Lerbin, R. (2007). Riset Pemasaran: Teori dan Praktik (1 ed.). Bogor: Ghalia Indonesia.

Azwar, S. (2012). Penyusunan Skala Psikologi edisi 2. Yogyakarta: Pustaka Pelajar.

Balkis, A. S., \& Masykur, A. M. (2016). Memahami Subjective Well-Being Guru Honorer Sekolah Dasar Negeri (Sebuah Studi Kualitatif Fenomenologis). Jurnal Empati, 5(2), 223-228.

Chatib, M. (2011). Gurunya manusia menjadikan semua anak istimewa dan semua anak juara. Bandung: Kaifa.

Kemendikbud. (2017, Juni 14). Retrieved September 4, 2018, from Tahun Pelajaran 2017/2018, Guru Wajib di Sekolah 40 Jam per Minggu: https://www.kemdikbud.go.id/main/blog/ 2017/06/tahun-pelajaran-20172018-guruwajib-di-sekolah-40-jam-per-minggu

Laine, S. (2018). Occupational Well-being in School Communities - Action Research in Finnish and Estonian Schools 2009-2014. Finland: University Of Eastern Finland.

Lufri. (2013). Mengungkap Permasalahan Guru Profesional Di Sumatera Barat Berdasarkan Tinjauan Beban Mengajar 24 Jam. Prosiding Semirata FMIPA Universitas Lampung, 59-66.

Meiza, C. (2016). Perbedaan Kebahagiaan Pada Guru Berstatus Pns Dan Honorer. Jurnal Ilmiah Psikologi, 9(2), 34-37.

Mulyasa. (2013). Menjadi Guru Profesional. Bandung: Remaja Rosdakrya.

Nurwana. (2013). Perbandingan Tingkat Kepuasan Kerja Antara Guru Tetap dan Guru Honorer Pada Unit Pelaksana Teknis Dinas Pendidikan Kecamatan
Kasui Kabupaten Waykana.Tesis. Jakarta: Progam Pascasarjana Universitas Terbuka.

Ramadhan, N. (2017). Tugas, Peran Kompetensi Dan Tanggungjawab Menjadi Guru Profesional. Prosiding Seminar Nasional Tahunan (pp. 369-374). Medan: Fakultas Ilmu Sosial Universitas Negeri Medan.

Saaranen, T. T. (2012). The Occupational Well-Being Of School Staff And Maintenance Of Their Ability To Work In Finland And Estonia - Focus On The School Community And Professional Competence. Journal Health Education, $112(3), 236-225$.

Saaranen, T., Tossavainen, K., Turunen, H., Kiviniemi, V., \& Vertio, H. (2006). Occupational Wellbeing In A school Community-Staff's Aand Occupational Healt Nurses' Evaluations. Journal Teaching and Teacher Education, 22, 740-752.

Saaranen, T., Tossavainen, K., Turunen, H., Vesa, K., \& Vertio, H. (2007). Occupational Well-Being Of School Staff Members: A Structural Equation Model. Journal Health Education Research, 22(2), 248-260.

Saaranen, T., Tossavainena, K., Turunena, H., \& Vertio, H. (2015). Occupational Well-being of School Staff. Experiences and results from an action research project realised in Finland and Estonia in 2009-2014. Kuopio, Finland: University of Eastern Finland.

Shabir, M. (2015). Kedudukan Guru Sebagai Pendidik: (Tugas dan Tanggung Jawab, Hak dan Kewajiban, dan Kompetensi Guru). Auladuna, 2(2), 221-232.

Sukardi. (2008). Metodologi Penelitian Pendidikan: Kompetensi dan Praktiknya (1 ed.). Jakarta: Bumi Aksara.

Suwandi. (2012, Oktober). Faktor - Faktor Yang Mempengaruhi Penghasilan Guru Di Era Disentralisasi Pendidikan. Jurnal Economia, 8(2). 
Suyatno, M. A. (2001). Psikologi Industri dan Organisasi. Jakarta: Universitas Indonesia.

Zain, I. (2017, November 24). Begini Cara Sekolah Menghitung Gaji Guru Honorer. Retrieved Oktober 24, 2018, from Kompasiana:

https://www.kompasiana.com/ikromzzzt/5 a14eaee9f91 ce0a834a35d3/bagaimana-se kolah-menghitung-gaji-guru-honorer?pag $\mathrm{e}=$ all

Zetriuslita, \& Wahyuni, R. (2013). Hubungan Motivasi Kerja Dan Kesejahteraan Terhadap Kinerja Guru Matematika Sekolah Menengah Pertama Di Kota Pekanbaru. Jurnal Pendidikan Matematika dan Sains, 1(1), 50-62. 